\title{
PROBLEMATIC INTERNET USAGE BY ADOLESCENTS WITH DISABILITIES
}

\author{
I. P. Volkova ${ }^{1}$, N. N. Koroleva ${ }^{2}$, I. M. Bogdanovskaya ${ }^{3}$, \\ G. Yu. Ikonnikova ${ }^{4}$, A. V. Mashkova ${ }^{5}$
}

Herzen State Pedagogical University of Russia, St. Petersburg, Russia. E-mail:1olkova52@mail.ru; ${ }^{2 k}$ korolevanatalya@mail.ru; 3ibogdanovs@herzen.spb.ru; 4ikonnikova@inbox.ru; ${ }^{5}$ amashkova@herzen.spb.ru

Abstract. Introduction. The intensive development of adaptive information technologies leads to the active inclusion of adolescents with disabilities in Internet communications, expanding the possibilities of their social adaptation. At the same time, the limitation of opportunities for social interaction due to impaired psychophysical development is an additional factor in the uncontrolled involvement of adolescents in Internet communication and the risk of Problematic Internet Usage.

The aim of this research is to study the degree and indicators of Internet addiction among adolescents with disabilities in conjunction with indicators of their social adaptability.

Methodology and research methods. Theoretical and empirical study is based on the provisions of the psychological theory of activity and personality, cultural-historical theory of L. S. Vygotsky, the ideas of domestic and foreign psychology about addictive behaviour including about risk and factors of Internet addictive behaviour normally developing adolescents and adolescents with disabilities. The study was carried out using empirical methods (questionnaires, psycho-diagnostic methods, survey methods); methods of quantitative analysis of empirical data, including methods of mathematical statistics: comparison of samples by the Mann-Whitney test; correlation analysis using the linear Pearson correlation coefficient. The calculations were performed using the Excel software package and using the SPSS 16.0 software package (Statistical Package for Social Science).

Research results and scientific novelty. The general and specific features of the Internet usage among adolescents with disabilities are identified; personality traits are identified as a prerequisite for the Problematic Internet Usage in this category of adolescents. It has been determined that virtual communication acts for adolescents with disabilities as a kind of adaptation-compensatory resource that allows overcoming communicative difficulties. At the same time, inadequate selfregulation of behaviour makes it difficult for self-control to stay online and the-

Образование и наука. Том 21, № 9. 2019/The Education and Science Journal. Vol. 21, № 9. 2019 
reby increases the risk of the negative impact of interaction on the Internet on their physical and mental state. It is revealed that the personal background of the Problematic Internet Usage has specificity depending on the nature of developmental disorders in adolescents.

Practical significance. The results of the research can be used in the work of a psychologist and a teacher for the diagnosis, prevention and correction of Internet addiction by adolescents with disabilities.

Keywords: assistive technologies, Problematic Internet Usage, addictive behaviour, internet addiction, adolescents with disabilities, disabled people, social integration, social adaptation, personality traits.

Acknowledgements. The study was conducted with the organisational support of educational institutions of St. Petersburg (Elizarova Yu. G., Director of School № 522, Admiralty district of St. Petersburg; Mukhin A. V., Director of the Boarding School № 1 named after K. K. Grotto, Krasnogvardeisky district of St. Petersburg; Beinarovich K. K., Director of Boarding School № 2, Kirov district of St. Petersburg). The authors are grateful to the reviewers for the in-depth analysis of the article materials, which significantly improved its quality, and are also thankful for those who took an active part in the experiment.

For citation: Volkova I. P., Koroleva N. N., Bogdanovskaya I. M., Ikonnikova G. Yu., Mashkova A. V. Problematic Internet usage by adolescents with disabilities. The Education and Science Journal. 2019; 9 (21): 98-121. DOI: 10.17853/1994-5639-2019-9-98-121

\title{
ПРОБЛЕМНОЕ ИСПОЛЬЗОВАНИЕ ИНТЕРНЕТА ПОДРОСТКАМИ С ОГРАНИЧЕННЫМИ ВОЗМОЖНОСТЯМИ ЗДОРОВЬЯ
}

\author{
И. П. Волкова ${ }^{1}$, Н. Н. Королева ${ }^{2}$, И. М. Богдановская ${ }^{3}$, \\ Г. Ю. Иконникова ${ }^{4}$, А. В. Машкова ${ }^{5}$
}

Российский государственный педагогический университет им. А. И. Гериена, Санкт-Петербург, Россия.

E-mail: ${ }^{1}$ volkova52@mail.ru; ${ }^{2 k}$ orolevanatalya@mail.ru;

3ibogdanovs@herzen.spb.ru; ${ }^{4}$ ikonnikova@inbox.ru; ${ }^{5}$ amashkova@herzen.spb.ru

Аннотация. Введение. Интенсивно развивающиеся адаптивные информационные технологии, с одной стороны, позволяют мюдям с ограниченными возможностями здоровья (ОВЗ) активно включаться в дистанционные коммуникации, что существенно облегчает процессы их социальной адаптации. С другой стороны, неконтролируемое использование Интернета и нели- 
митированное общение в сети, особенно в подростковом возрасте, явАяются дополнительными факторами риска, возрастающего в случае нарушений психофизического развития.

Цель представленной в статье работы - изучение проблемы интернетзависимости старших школьников с ОВЗ в ее взаимосвязи с уровнем их социальной адаптированности.

Методология и методики. Теоретико-эмпирическое исследование реализовано с опорой на положения культурно-исторической теории $\Lambda$. С. Выготского и представления отечественной и зарубежной психологии о проблемном использовании Интернета и об интернет-аддикции у нормально развивающихся подростков и их сверстников с ОВЗ. В ходе изыскания использоваиись такие эмпирические методы, как анкетирование, психодиагностика и опрос; а также качественный и количественный виды анализа полученных данных, включая методы математической статистики (сравнение показателей выборок по критерию Манна-Уитни); корреляционный анализ с применением Аинейного коэффициента корреляции Пирсона. Вычисления проводимись с помощью пакета программ "Excel» и SPSS 16.0 (Statistical Package for Social Science - Статистический пакет для социальных наук).

Результаты и научная новизна. Установлены общие и специфические особенности поведения старших школьников с ОВЗ в сети Интернет. Выявцены качества Аичности, служащие предпосылками формирования интернет-зависимости у данной категории учащихся. Утверждается, что виртуальная коммуникация дмя подростков с ОВЗ выступает своего рода адаптационнокомпенсаторным ресурсом, помогающим преодолевать коммуникативные сложности. В то же время недостаточная саморегуцяция поведения затрудняет самоконтроль в периоды пребывания в сети, что увеличивает риски негативного вАияния взаимодействий с Интернетом на физическое и психическое состояние. Индивидуальные предпосылки проблемного использования виртуального пространства обусловлены характером психофизических нарушений у подростка с ОВЗ.

Практическая значимость. Материалы и результаты исследования могут быть использованы в работе психологов и педагогов дмя диагностики, профимактики и коррекции интернет-зависимости старших школьников с ОВЗ.

Ключевые слова: ассистивные компьютерные технологии, проблемное использование Интернета, аддиктивное поведение, интернет-аддикция, подростки с ограниченными возможностями, инвалиды, социальная адаптация, социальная интеграция, черты Аичности.

Благодарности. Авторы благодарят всех участников исследовательского эксперимента и представителей администраций образовательных учреждений г. Санкт-Петербурга за его организационную поддержку - преж-

Образование и наука. Том 21, № 9. 2019/The Education and Science Journal. Vol. 21, № 9. 2019 
де всего, директора школы № 522 Адмиралтейского района Ю. Г. Елизарову, директора школы-интерната № 1 им. К. К. Грота Красногвардейского района А. В. Мухина и директора школы-интерната № 2 Кировского района K. К. Бейнаровича. Авторы также выражают признательность анонимным рецензентам журнала за глубокий анализ текста статьи, позволивший существенно улучшить ее качество.

Для иитирования: Волкова И. П., Королева Н. Н., Богдановская И. М., Иконникова Г. Ю., Машкова А. В. Проблемное использование Интернета подростками с ограниченными возможностями здоровья // Образование и наука. 2019. Т. 21, № 9. С. 98-121. DOI: 10.17853/1994-5639-2019-9-98-121

\section{Introduction}

Currently, the Internet is becoming an integral part of human life, a way of obtaining information and communication for people of different social status and age. Humanisation of society necessitates overcoming information barriers, providing access to modern information resources and network technologies for people with disabilities. Nowadays, such people are becoming active users of the network space due to assistive technology, adapted technical means allowing access to the Internet (tactile displays for the blind, various modifications of keyboards and manipulators for people with disabilities of the musculoskeletal system, special devices for people with hearing and speech impairments, etc.). Modern information and communication technologies have great rehabilitation capabilities: their development allows people with sensory and intellectual impairments to join different spheres of life along with healthy people, helps to expand their independence, and, ultimately, overcome their isolation in society. The Internet is becoming a special sociocultural space, one of the main factors for improving the quality of life, social adaptation and inclusion in the public life of people with disabilities [18]. At the same time, active using of modern means of communication by persons with physical and intellectual disabilities, as well as users without disabilities, can have negative consequences for the mental and personal development of a person, and lead to the formation of a special form of behaviour the Problematic Internet Usage (PIU).

\section{Literature Review}

The increasing importance of computer and network technologies in modern life leads to the formulation of the problem of analysing the differences between the normative and Problematic Internet Usage, highlighting the 
criteria for diagnosing these forms of behaviour. Considering information and communication technologies as an achievement of scientific and technological progress, as a new social reality, some authors question the legitimacy of identifying such a form of Internet addiction, consider Problematic Internet Usage by a person as a manifestation of the modern social reality, as a mass culture phenomenon. Internet addiction is considered, like other forms of addictive behaviour, as a global problem of modern humanity as a whole [4, 911]. At the same time, it is necessary to distinguish between regulatory use, Internet addiction and Problematic Internet Usage, understanding the sufficient measure of the conventionality of such a distinction. The term "Internet addiction" implies a special kind of behavioural disorder, which manifests itself in such characteristics as constant Internet preoccupation, withdrawal syndrome (marked deterioration of well-being and emotional state when Internet use is discontinued), tolerance (increasing the time spent on the network to get positive emotions), loss of interest in other activities, etc. [12-19]. Problematic Internet Usage implies a long and intensive network interaction, which, however, is not described in terms of the norm and pathology [20-22]. A number of studies emphasise the special relevance of studying the influence of Internet technologies on the level of an individual's adaptation to the social environment, and the analysis of personal characteristics of users with regulatory and Problematic Internet Usage. Socio-psychological characteristics and personality traits of Problematic Internet Usage determine the direction of the individual's adaptation to a new social reality, which can lead towards both adaptation and maladaptation [8, 23-24].

With the spread of computer technology and mobile devices, the number of Internet users is rapidly growing among adolescents, including adolescents with disabilities. At the same time, children and adolescents are most vulnerable to various kinds of negative impacts, which lead to an increased risk of the formation of their addiction on computer tools and cyber communication. Psychological features of the pubertal period are distinguished as risk factors for Problematic Internet Usage among adolescents: increased sensitivity to external influences, restructuring of previously established psychological personality structures, emotional instability, reduced ability to self-regulate and self-control, low emotional and social competence [16, 21, 24-27].

The impact of network interaction on the mental and personal development of a teenager is assessed ambiguously. Thus, the use of computer video games in the process of educational activity can have a positive effect on the development of attention, especially by children with disabilities. Computer video games, which basically contain elements of interactivity, can stimulate 
learning, help overcome the social and emotional difficulties of children with autism spectrum disorders, and improve the recognition of those around them in this category of children [1-3, 27-28]. There is some evidence of the positive significance of YouTube as one of the most popular site among modern teenagers for their self-realisation, the disclosure of young talents in various fields [29]. At the same time, adolescents with disabilities are more susceptible to threats to the security of network interaction, cyberbullying [30]. Uncontrolled use of dating sites can create a risk of online aggression, possible sexual harassment online, victimisation of personality, especially among adolescents with cognitive impairments who are characterised by reduced will control, impulsivity in their behaviour [27].

Thus, despite the increased risk of possible Internet addiction, the use of modern computer technologies by teenagers with disabilities can be a significant factor in compensating for the consequences of their sensory, emotional, cognitive and social deprivation. Socio-psychological characteristics and personality traits of adolescent children with developmental problems determine the direction of their adaptation vector to a new social reality, which can lead both towards adaptation and disadaptation. This determines the special relevance of the study of the personal characteristics of adolescents with disabilities with regulatory and Problematic Internet Usage.

\section{Materials and methods}

Theoretical and empirical study is based on the provisions of the psychological theory of activity and personality, cultural-historical theory of L. S. Vygotsky [31], the ideas of Russian and foreign psychology about addictive behaviour [12-14, 20, 32] including about risk and factors of the formation of Internet addictive behaviour normally developing adolescents and adolescents with disabilities $[1-4,15,21,25,26]$. The participants were 90 students from grades 9 and 10 of secondary schools in St. Petersburg (Russian Federation). Of these participants, 30 people - normally developing schoolchildren, who had no problems with education (22 female, 8 male; $\mathrm{M}=16.03, \mathrm{SD}=1.12$ ); the second group included 20 adolescents with learning problems ( 6 female, 14 male; $\mathrm{M}=15.8, \mathrm{SD}=1.03$ ). The third and fourth group included adolescents with disabilities: 20 visually impaired teenagers (10 female, 10 male; $\mathrm{M}=15.8, \mathrm{SD}=1.13$ ) and 20 blind teenagers (12 female, 8 male; $\mathrm{M}=15.5, \mathrm{SD}=1.08$ ).

The method of screening diagnostics of Internet addiction was employed [32]. This method is a screening questionnaire designed to detect Internet addiction and has been developed and adapted for using in the Russian-spe- 
aking environment of L. N. Yurieva and T. Yu. Bolbot [32]. In developing of the methodology, the authors were guided by the criteria for diagnosing Internet addiction [33-34]. The questionnaire includes statements regarding emotions and feelings associated with being on-line; time spent on social networks, attitudes to social conditions and duties due to being on the Internet, the influence of a computer on the psychophysical state, sleep and wakefulness. The questionnaire consists of 11 items, assessing on a four-point scale ( 1 - never, 2 - rarely, 3 - often, 4 - very often) and functions as a single scale - "Overall level of Internet addiction)", Cronbach's alpha: 0.753. Following authors, we adopted this cutoff value to classify normal Internet use (0-22), Problematic Internet Usage (23-44).

Table 1

Results of screening diagnostics of Internet Addiction, \%

\begin{tabular}{|l|c|c|c|c|}
\hline $\begin{array}{c}\text { Level of Internet } \\
\text { Addiction }\end{array}$ & $\begin{array}{c}\text { Teenagers } \\
\text { without he- } \\
\text { alth and le- } \\
\text { arning prob- } \\
\text { lems }\end{array}$ & $\begin{array}{c}\text { Teenagers } \\
\text { with lear- } \\
\text { ning prob- } \\
\text { lems }\end{array}$ & $\begin{array}{c}\text { Visually im- } \\
\text { paired te- } \\
\text { enagers }\end{array}$ & $\begin{array}{c}\text { Blind teena- } \\
\text { gers }\end{array}$ \\
\hline Normal Internet Use & 46 & 20 & 10 & 40 \\
\hline $\begin{array}{l}\text { Problematic Internet } \\
\text { Use }\end{array}$ & 54 & 80 & 90 & 60 \\
\hline
\end{tabular}

This study applied the diagnostics of cyber communication addiction [16]. In this survey, the focus is on the study of the most common forms of Internet addiction - cyber communication addiction, caused by excessive communication in a social network. In developing the questionnaire, the author was guided by such criteria as cyber communication addiction, salience, tolerance, mood modification, relapse, withdrawal, conflict. The survey consists of 20 items, assessing on a five-point scale $(1-$ never, 2 - hardly ever, 3 - rarely, 4 - often, 5 - very often) and functions as a single scale - "Overall level of cyber communication addiction”, Cronbach's alpha: 0.958. Survey test / re-test correlation showed a good performance on reliability (a Pearson's correlation coefficient 0.742 ). Following the author, we adopted this cutoff value to classify normal cyber communication (50-79), problematic cyber communication (80-100).

High School Personality Questionnaire (HSPQ) was used. HSPQ is a standardised test, measuring 14 distinct dimensions or personality traits. These 14 factors can obtain predictions of school achievement, danger of delinquency, need for clinical help in neurotic condition, etc. The reading level of the test is adapted to ages $11-12$ to 18 . 
Table 2

Results of screening diagnostics of cyber communication addiction, \%

\begin{tabular}{|l|c|c|c|c|}
\hline \multicolumn{1}{|c|}{$\begin{array}{c}\text { Level of Cyber } \\
\text { Addiction }\end{array}$} & $\begin{array}{c}\text { Teenagers } \\
\text { without he- } \\
\text { alth and le- } \\
\text { arning prob- } \\
\text { lems }\end{array}$ & $\begin{array}{c}\text { Teenagers } \\
\text { with lear- } \\
\text { ning prob- } \\
\text { lems }\end{array}$ & $\begin{array}{c}\text { Visually im- } \\
\text { paired te- } \\
\text { enagers }\end{array}$ & $\begin{array}{c}\text { Blind teena- } \\
\text { gers }\end{array}$ \\
\hline $\begin{array}{l}\text { Normal Cyber Com- } \\
\text { munication }\end{array}$ & 60 & 50 & 30 & 70 \\
\hline $\begin{array}{l}\text { Problematic Cyber } \\
\text { Communication }\end{array}$ & 40 & 50 & 70 & 30 \\
\hline
\end{tabular}

The main standard scores are stems, in which a person can score from 1 to 10. Brief description of the14 HSPQ personality factors: A-Warmth (Reserved - Out-going), B-Reasoning (Less - More), C-Emotional stability (Changeable - Stable), D-Excitability (Phlegmatic - Excitable), E-Dominance (Compliant - Dominant), F-Cheerfulness (Sober - Enthusiastic), G-Consciousness (Rebellious - Rule-bound), H-Social boldness (Shy - Extroverted), I-Sensitivity (Realistic - Sensitive), J-Withdrawal (Vigorous - Doubtful), O-Apprehension (Placid - Apprehensive), Q2-Self-sufficiency (Dependent - Resourceful), Q3Self-discipline (Undisciplined - Controlled), Q4- tension (Relaxed - Tense).

The multilevel Personality Questionnaire of Adaptability (MPQA) was employed. MPQA is designed to study the adaptive capacity of the individual based on the assessment of some psycho-physiological and socio-psychological characteristics, which reflect the integral features of mental and social development. MPQA is a standardised test; the main standard scores are stems, in which a person can score from 1 to 10 . The questionnaire has three subscales: behavioural regulation (BR) - the ability of a person to regulate their interaction in the environment, based on positive self - esteem and emotional stability; communicative skills $(\mathrm{CS})$ - the ability to reach understanding with other people; moral normativity (MN) - the ability to adequately perceive their social role, adhere to moral norms. The summarising scale of the questionnaire - Personal potential of social and psychological adaptation (PAP) was used. The test/retest reliability for the various scales has values between 0.583 and 0.78 . The internal reliability was determined by a method of split-half (Cronbach's alpha $=0.437$ to 0.675 ).

In this study, we conduct the ANOVA to examine the Internet addiction behaviour and cyber communicative addiction scores in different groups of independent variables (students without health and learning problems, students with learning problems, visually impaired teenagers, and blind teena- 
gers). The Scheffe test is correcting the accounts for multiple comparisons and Pearson's correlation to examine the associations between Internet addiction and cyber communication addiction scores and other variables. Statistical significance was set at a level of $\mathrm{p}<0.05$. The Statistica 10.0 software package was used for analyses in this study.

\section{Results}

Table 3 shows the statistically significant differences in the parameters studied in the characteristics of the Problematic Internet Usage and sociopsychological adaptation in the studied groups. As shown by the results obtained by the method - Method of screening diagnostics of Internet addiction [32], Problematic Internet Usage is typical for all groups of adolescents. However, the most compulsive interaction in the network, neglecting other responsibilities to be online, difficulties with management of time spent on line, the negative impact of network communication on the physical and mental state are expressed by visually impaired adolescents. Excessive Internet enthusiasm is also in largely characteristic for adolescents with learning difficulties. The least pronounced signs of the Problematic Internet Usage among blind adolescents and their practically healthy peers. The highest values of the social communication enthusiasm indicator, identified through the Diagnostics cyber communication addiction questionnaire [16], are also observed in the groups of visually impaired and adolescents with learning difficulties.

Table 3

Means and SD of overall level of cyber communication and Internet addiction

\begin{tabular}{|c|c|c|c|c|c|c|c|c|c|}
\hline \multirow[t]{2}{*}{ Variables } & \multicolumn{2}{|c|}{$\begin{array}{c}\text { Teenagers } \\
\text { without disa- } \\
\text { bilities } \\
\end{array}$} & \multicolumn{2}{|c|}{$\begin{array}{c}\text { Teenagers } \\
\text { with learning } \\
\text { problems }\end{array}$} & \multicolumn{2}{|c|}{$\begin{array}{l}\text { Visually im- } \\
\text { paired teena- } \\
\text { gers }\end{array}$} & \multicolumn{2}{|c|}{$\begin{array}{l}\text { Blind teena- } \\
\text { gers }\end{array}$} & \multirow[t]{2}{*}{$\begin{array}{l}\text { Adjus- } \\
\text { ted } \\
\text { p-value }\end{array}$} \\
\hline & $\mathrm{M}$ & $\mathrm{SD}$ & $\mathrm{M}$ & $\mathrm{SD}$ & $\mathrm{M}$ & $\mathrm{SD}$ & $\mathrm{M}$ & SD & \\
\hline $\begin{array}{l}\text { Overall level of } \\
\text { cyber communi- } \\
\text { cation addiction }\end{array}$ & 44.97 & 12.08 & 50.90 & 16.74 & 57.9 & 21.54 & 45.9 & 11.56 & 0.02 \\
\hline $\begin{array}{l}\text { Overall level of } \\
\text { Internet addicti- } \\
\text { on }\end{array}$ & 25.57 & 9.21 & 34.20 & 14.13 & 33.6 & 9.0 & 26.9 & 9.50 & 0.01 \\
\hline
\end{tabular}

Significant differences in the characteristics of socio-psychological adaptation (Multilevel Personality Questionnaire of Adaptability (MPQA)) between groups of adolescents with learning difficulties, blind, visually impaired and adolescents without developmental disorders are revealed (Table 4). 
Table 4

Means and SD of parameters of adaptability

\begin{tabular}{|l|c|c|c|c|c|c|c|c|c|}
\hline \multirow{2}{*}{ Variables } & \multicolumn{2}{|c|}{$\begin{array}{c}\text { Teenagers } \\
\text { without disa- } \\
\text { bilities }\end{array}$} & \multicolumn{2}{|c|}{$\begin{array}{c}\text { Teenagers } \\
\text { with learning } \\
\text { problems }\end{array}$} & \multicolumn{2}{c|}{$\begin{array}{c}\text { Visually im- } \\
\text { paired teena- } \\
\text { gers }\end{array}$} & \multicolumn{2}{c|}{$\begin{array}{c}\text { Blind teena- } \\
\text { gers }\end{array}$} & $\begin{array}{c}\text { Adjus- } \\
\text { ted } \\
\text { p-value }\end{array}$ \\
\cline { 2 - 10 } & $\mathrm{M}$ & $\mathrm{SD}$ & $\mathrm{M}$ & $\mathrm{SD}$ & $\mathrm{M}$ & $\mathrm{SD}$ & $\mathrm{M}$ & $\mathrm{SD}$ & \\
\hline $\begin{array}{l}\text { Behavioural re- } \\
\text { gulation (BR) }\end{array}$ & 4.47 & 2.13 & 2.40 & 1.58 & 3.40 & 2.22 & 2.60 & 1.35 & 0.00 \\
\hline $\begin{array}{l}\text { Communicative } \\
\text { skills (CS) }\end{array}$ & 4.83 & 1.53 & 3.40 & 1.07 & 3.70 & 1.64 & 3.20 & 1.14 & 0.00 \\
\hline $\begin{array}{l}\text { Moral normati- } \\
\text { vity (MN) }\end{array}$ & 4.93 & 2.00 & 3.50 & 1.35 & 4.40 & 1.43 & 4.90 & 1.10 & 0.01 \\
\hline $\begin{array}{l}\text { Personal poten- } \\
\text { tial of social and } \\
\text { psychological } \\
\text { adaptation (PAP) }\end{array}$ & 4.13 & 2.21 & 1.60 & 1.07 & 2.50 & 1.78 & 4.60 & 1.58 & 0.00 \\
\hline
\end{tabular}

Thus, adolescents with learning difficulties and blind adolescents are characterised by the lowest level of ability to self-regulate behaviour (behavioural regulation), low self-esteem and low emotional stability. Blind adolescents with a sufficiently high level of general adaptation potential have the most pronounced difficulties in communication, a low level of communication skills development, and are prone to manifestations of conflict in communication. Adolescents with learning difficulties have a low level of moral standardisation, have difficulty in assessing their role and place in a social group, and do not strive to comply with generally accepted standards of behaviour. The overall level of personal adaptation potential is the lowest in the group of adolescents with learning difficulties. Such adolescents have difficulties in adapting to the new conditions of communication and activity, increased conflict and aggressiveness, expressed emotional instability, weakened self-regulation of behaviour. Visually impaired adolescents also have trouble in social adaptation. Significant differences in the severity of personality traits that were detected through the High School Personality Questionnaire (HSPQ) were not found in the groups studied. As a result of the correlation analysis, statistically significant interrelationships of the characteristics of the Problematic Internet Usage (tendency toward Internet addiction behaviour and excessive virtual communication) with indicators of social adaptation and personality traits in each group of adolescents were identified (Table 5).

Thus, in the group of adolescents with normative development, a positive relationship between the indicators of propensity for Internet addiction and passion for communication in social networks was found. At the same time, 
the tendency to Internet addiction behaviour has a negative relationship with the moral standard of behaviour of rule-consciousness (factor G).

Table 5

Teenagers without disabilities: correlation coefficients between indicators of indicators of cyber communication and Internet addiction, personal trait, indicator of behavioural regulation, means, SD

\begin{tabular}{|l|c|c|c|c|c|c|c|c|}
\hline \multicolumn{1}{|c|}{ Variables } & 1 & 2 & 3 & 4 & 5 & 6 & Means & SD \\
\hline $\begin{array}{l}\text { Overall level of } \\
\text { cyber communi- } \\
\text { cation addiction }\end{array}$ & - & & & & & & 44.96 & 12.07 \\
\hline $\begin{array}{l}\text { Overall level of } \\
\text { Internet addicti- } \\
\text { on }\end{array}$ & $0.55^{* *}$ & - & & & & & 25.56 & 9.20 \\
\hline Factor D & 0.23 & $0.42^{*}$ & - & & & & 6.20 & 4.01 \\
\hline Factor G & -0.38 & 0.12 & 0.05 & - & & & 8.80 & 3.66 \\
\hline Factor Q3 & -0.18 & $-0.41^{*}$ & 0.05 & -0.07 & - & & 9.60 & 3.12 \\
\hline $\begin{array}{l}\text { Behavioural re- } \\
\text { gulation (BR) }\end{array}$ & $0.51^{* *}$ & $-0.39^{*}$ & -0.29 & 0.28 & 0.18 & - & 4.46 & 2.12 \\
\hline
\end{tabular}

Note: ${ }^{*} \mathrm{p}<0.05 ;{ }^{* *} \mathrm{p}<0.01$

Excessive network communication in this group has a direct relationship with excitability, impatience (factor D), and a reverse relationship with volitional self-control behaviour (factor Q3). Problematic Internet Usage and enthusiasm for virtual communication are negatively associated with an indicator of behavioural self-regulation (MPQA questionnaire).

In the group of adolescents with learning difficulties (Table 6), indicators of propensity for Internet addiction and excessive network communication are closely related. They positively correlate with such personality traits as ability to abstract thinking (factor B), emotional sensitivity (factor I), and negatively - with the indicator of communicative skills (MPQA questionnaire).

At the same time, the indicator of Problematic Internet Usage has a positive relationship with emotional stability (factor $\mathrm{C}$ ). The indicator of involvement in virtual communication is associated with such personality traits as enterprise, energy, and preference for group communication (negative correlation with factor $\mathrm{J}$ ).

In the group of blind adolescents (Table 7), there was also a strong positive relationship between the indicators of Internet and cyber addiction. Both of these indicators, as well as among teenagers with learning difficulties, have positive interrelations with abstract thinking and internal tension, frustration (factors B and Q4). At the same time, negative correlation of these in- 
dicators with self-regulation of behaviour and communication skills was revealed. Blind adolescents also have a negative relationship with overall level of Internet addiction and the overall level of personal adaptation potential. The excessive virtual communication is associated with low activity, phlegm and preference for group communication (feedback with factors D and J).

Table 6

Teenagers with learning difficulties: correlation coefficients between indicators of cyber communication and Internet addiction, personal trait, indicator of ccommunication skills, means, SD

\begin{tabular}{|l|l|l|l|l|l|l|l|c|}
\hline \multicolumn{1}{|c|}{ Variables } & 1 & 2 & 3 & 4 & 5 & 6 & Means & SD \\
\hline $\begin{array}{l}\text { Overall level of } \\
\text { cyber communi- } \\
\text { cation addiction }\end{array}$ & - & & & & & & 50.90 & 16.29 \\
\hline $\begin{array}{l}\text { Overall level of In- } \\
\text { ternet addiction }\end{array}$ & $0.8^{* * *}$ & - & & & & & 34.20 & 13.76 \\
\hline Factor B & $0.49^{*}$ & $0.58^{* *}$ & - & & & & 4.60 & 1.67 \\
\hline Factor C & $0.52^{*}$ & 0.43 & -0.25 & - & & & 8.00 & 5.11 \\
\hline Factor I & $0.51^{*}$ & 0.51 & $0.60^{* *}$ & -0.04 & - & & 5.40 & 1.85 \\
\hline $\begin{array}{l}\text { Communicatives- } \\
\text { kills (CS) }\end{array}$ & $-0.64^{* *}$ & $-0.48^{*}$ & -0.27 & -0.28 & -0.31 & - & 3.40 & 1.05 \\
\hline
\end{tabular}

Note: ${ }^{*} \mathrm{p}<0.05 ;{ }^{* *} \mathrm{p}<0.01,{ }^{* * *} \mathrm{p}<0.001$

Table 7

Blind teenagers: correlation coefficients between indicators of cyber communication and Internet addiction, personal trait, indicator of personal potential of social and psychological adaptation, means, SD

\begin{tabular}{|l|c|c|c|c|}
\hline \multicolumn{1}{|c|}{ Variables } & 1 & 2 & Means & SD \\
\hline $\begin{array}{l}\text { Overall level of cyber communi- } \\
\text { cation addiction }\end{array}$ & - & & 45.90 & 11.25 \\
\hline $\begin{array}{l}\text { Overall level of Internet addicti- } \\
\text { on }\end{array}$ & $0.90^{* * *}$ & - & 26.90 & 9.25 \\
\hline Factor B & $0.77^{* * *}$ & $0.80^{* * *}$ & 3.10 & 0.85 \\
\hline Factor D & -0.42 & $-0.56^{*}$ & 6.60 & 2.26 \\
\hline Factor J & -0.27 & $-0.48^{*}$ & 6.20 & 2.14 \\
\hline Factor Q4 & $0.58^{* *}$ & 0.38 & 4.80 & 2.28 \\
\hline Behavioural regulation (BR) & $-0.72^{* * *}$ & $-0.59^{* *}$ & 2.60 & 1.31 \\
\hline Communicative skills (CS) & $-0.62^{* *}$ & $-0.60^{* *}$ & 3.20 & 1.11 \\
\hline $\begin{array}{l}\text { Personal potential of social and } \\
\text { psychological adaptation (PAP) }\end{array}$ & $-0.63^{* *}$ & -0.40 & 4.60 & 1.54 \\
\hline
\end{tabular}

Note: ${ }^{*} \mathrm{p}<0.05 ;{ }^{* *} \mathrm{p}<0.01 ;{ }^{* *} \mathrm{p}<0.001$ 
The largest number of statistically significant links between indicators of Problematic Internet Usage, personality traits and characteristics of social adaptation were found in the group of visually impaired adolescents (Table 8).

Table 8

Visually impaired teenagers: correlation coefficients between indicators of cyber communication and Internet addiction, personal trait and indicator of personal potential of social and psychological adaptation, means, SD

\begin{tabular}{|l|c|c|c|c|}
\hline \multicolumn{1}{|c|}{ Variables } & 1 & 2 & Means & SD \\
\hline $\begin{array}{l}\text { Overall level of cyber communi- } \\
\text { cation addiction }\end{array}$ & - & & 57.90 & 20.97 \\
\hline $\begin{array}{l}\text { Overall level of Internet addicti- } \\
\text { on }\end{array}$ & $0.75^{* * *}$ & - & 33.60 & 8.76 \\
\hline Factor D & $0.59^{* *}$ & $0.50^{*}$ & 5.40 & 2.60 \\
\hline Factor G & -0.39 & $-0.58^{* *}$ & 8.20 & 3.94 \\
\hline Factor J & $0.73^{* * *}$ & $0.72^{* * *}$ & 6.00 & 2.60 \\
\hline Factor O & $0.52^{*}$ & $0.50^{*}$ & 6.20 & 4.15 \\
\hline Factor Q3 & $-0.69^{* * *}$ & $-0.58^{* *}$ & 7.60 & 1.54 \\
\hline Behavioural regulation (BR) & -0.29 & $-0.46^{*}$ & 3.40 & 2.16 \\
\hline Communicative skills (CS) & $-0.72^{* * *}$ & $-0.64^{* *}$ & 3.70 & 1.59 \\
\hline Moral normativity (MN) & $-0.76^{* * *}$ & $-0.65^{* *}$ & 4.40 & 1.39 \\
\hline
\end{tabular}

Note: ${ }^{*} \mathrm{p}<0.05 ;{ }^{* *} \mathrm{p}<0.01 ;{ }^{* * *} \mathrm{p}<0.001$

So, the tendency to Internet and cyber communication addiction are associated with such personality traits as impatience and excitability, neurasthenia, individualism, anxiety and a penchant for guilt (positive correlations with factors $\mathrm{D}, \mathrm{J}, \mathrm{O}$ ), low self-control behaviour (negative correlation with factor Q3). Both indicators of the Problematic Internet Usage have negative connections with such indicators of socio-psychological adaptation as communication skills and moral standardisation of behaviour.

\section{Discussion}

The obtained results showed that, for adolescents, regardless of their health and psychophysical development, involvements in Internet communication, preferring to stay online to other types of activity are characteristic. This result is consistent with data of Swedish researchers Lidström H., Ahlsten G. and Hemmingsson $\mathrm{H}$. [35], who note that among the children with disabilities examined by them (215 people), the majority of children were characterised by Problematic Internet Usage. The authors explain the preference for this type of activity among children with disabilities by its ability to compensate for their violation, to provide them with wider access to communication. However, teenagers with disabilities are more prone to non-functional use of the Internet. They often experience positive 
emotions while on the Internet, neglect their social and everyday responsibilities due to being in cyberspace, note the negative impact of a computer on their psycho-physical state, but continue to spend a lot of time on the network. The presence of mental and physical developmental defects complicates the interaction of the child with the social environment, the possibility of achieving the goals within the frames of existing norm. Adolescents with disabilities are characterised by difficulties in social adaptation, which have certain features depending on the nature of develop-mental disorders. Significant differences in the severity of personality traits in adolescents without developmental disorders, with deep visual impairments and with learning difficulties were not found; nevertheless, the specificity of the interconnections between Problematic Internet Usage and the personality traits and characteristics of adolescents' personal adaptation potential has been determined.

Adolescents with difficulties in learning are characterised by the most pronounced problems in social adaptation, manifested primarily in the low level of personal adaptation potential and reduced self-control behaviour. The obtained data are consistent with the results of a numerous studies in which it was revealed that adolescents with learning difficulties and a low level of cognitive development are characterised by a weak formation of personal selfregulation, inadequate self-esteem, reduced criticality towards themselves, and social maladjustment. Probably, the compulsive uncontrolled use of the Internet by such adolescents is the result of insufficient self-regulation of behaviour in general. In adolescents with learning difficulties, Problematic Internet Usage is associated with a decrease in communication skills. More intensive Internet usage is typical for those adolescents with learning difficulties, who prefer group communication, possess emotional stability and more developed abstract thinking. The data that we obtained accord overall with the results of I. A. Korobeinikov indicating that adolescents with learning difficulties presupposes poorly developed self-control mechanisms, connected with Internet addictive behaviour [36-37].

Apparently, the Internet performs a compensatory communicative function for such adolescents, makes it easier to establish and maintain contacts, and join in group interaction in cyberspace.

In visually impaired adolescents compared to other groups are more intensely involved in cyber communication. They are overly passionate about social networking. They also revealed a low level of personal adaptation potential. For visually impaired adolescents, the tendency to Internet addiction mediated by the characteristics of social adaptation and personality traits. Compulsive non-functional Internet usage is characteristic for emotionally unstable visually impaired adolescents with a low level of self-control, the de- 
velopment of communication skills and a low moral standard of behaviour. This result is confirmed by A. G. Litvak, who pointed out that visually impaired adolescents often have significant difficulties in communication, in understanding social and group norms of interaction associated with the limitations of the visual perception of communication partners and characterised by emotional instability, sensitivity, reticence, communicative constriction [38-39]. Most likely, Internet communication, which does not have rigid rules and regulations, provides anonymous communication, does not require visual contact and the use of visual non-verbal means of communication, gives such adolescents more opportunities for self-disclosure, experiencing emotional comfort in interaction with other people.

Blind adolescents have the highest overall adaptive potential of the individual, which, apparently, is related to the fact that life activity in the conditions of visual deprivation requires a significant activation of adaptive resources. However, they have a low level of development of communication skills, which is also a consequence of a visual defect. This result is consistent with the study of E. S. Kostyuchenko, who notes that blind adolescents use the Internet mainly for social networking. The limited sensory experience and the predominantly verbal nature of communication, the possession of assistive information technologies give them the opportunity to feel more free and confident, to be equal interlocutors in a virtual interaction [40]. Problematic Internet Usage is characteristic of blind adolescents with a high level of verbal logical thinking, characterised by slowness, tending to group communication, but characterised by low self-control behaviour, internal tension and inadequate communication skills. It can be assumed that the involvement in the Internet communication of blind adolescents serves as a mean of compensating for reduced adaptation, inertia, slowness of reactions, as well as communication difficulties caused by visual deprivation. At the same time, low adaptation potential with high intelligence, phlegmatic and frustratedness is a risk factor for the Problematic Internet Usage for them.

In adolescents with a normative development, the Problematic Internet Usage is mediated by the volitional characteristics of the personality high impulsiveness, excitability, low level of volitional self-regulation, moral standardisation and self-control of behaviour.

\section{Conclusion}

Analysis of the results of the study showed that adolescents with disabilities, compared to their practically healthy peers, are more prone to Problematic Internet Usage. Virtual communication acts as a kind of adaptation-

Образование и наука. Том 21, № 9. 2019/The Education and Science Journal. Vol. 21, № 9. 2019 
compensatory resource for them, which allows overcoming communicative difficulties. At the same time, insufficient self-regulation of behaviour makes it difficult for self-control to stay online and thereby increases the risk of the negative impact of interaction on the Internet on their physical and mental state. The personal prerequisites for Problematic Internet Usage are specific, depending on the nature of developmental disorders in adolescents. Thus, in adolescents with learning difficulties, this is a combination of developed abstract thinking with a low level of moral standardisation and volitional selfcontrol, excitability, impulsiveness, and a desire to communicate in a group. For visually impaired adolescents, these prerequisites are emotional instability, anxiety, individualism, and low willed self-control. For blind adolescents - developed verbal and logical thinking, phlegmatic, internal tension, the desire for group interaction, low adaptability. The results can serve as a basis for developing programmes for the psychological prevention and correction of Problematic Internet Usage in adolescents with disabilities.

Prospects for further research are associated with identifying the specificity of Problematic Internet Usage in adolescents with other developmental disorders, including hearing impairment, the musculoskeletal system, as well as somatically impaired adolescents with chronic diseases. In addition, it seems appropriate to study in more detail the goals and motives of using the Internet, their interrelations with personality traits in adolescents with disabilities. The positive and negative aspects of the impact of involvement in Internet communication on the cognitive and personal development of adolescents with disabilities also deserve special attention.

\section{References}

1. Chakraborty J., Chakraborty S., Dehlinger J., et al. Designing video games for the blind: results of an empirical study. Universal Access in the Information Society [Internet]. 2017 [cited 2019 Jun 2]; 16 (3): 809-818. Available from: https:/ / doi.org/10.1007/s10209-016-0510-Z

2. Haage A., Bosse I. K. Media Use of Persons with Disabilities. In: International Conference on Universal Access in Human-Computer Interaction. Human and Technological Environments. Lecture Notes in Computer Science [Internet]; 2017 July 9-14; Vancouver, Canada. Springer, Cham; 2017. 10279. Available from: https://doi.org/10.1007/978-3-319-58700-4_34

3. Sallafranque-St-Louis F., Normand C. L. From solitude to solicitation: How people with intellectual disability or autism spectrum disorder use the Internet. Cyberpsychology: Journal of Psycho-Social Research on Cyberspace. 2017; 11 (1): article 7. DOI: 10.5817/CP2017-1-7

4. Belozerov S. A. Virtual worlds MMORPG. Part II. Remedy for social and psychological stress. Zhurnal Vysshej shkoly ehkonomiki = Journal of Higher School of Eco- 
nomics [Internet]. 2015 [cited 2019 Jun 2]; 12 (1): 71-89. Available from: https://psy-journal.hse.ru/data/2015/05/19/1097217643/PJHSE_1_2015_71_89.pdf (In Russ.)

5. Aleksadrova M. A., Zhivajkina A. A. The role of the Internet in the socialisation of people with disabilities. Byulleten' medicinskih Internet-konferencij $=$ Bulletin of Medical Internet Conferences. 2017; 7 (1): 48-49. (In Russ.)

6. Bukhtiyarova I. N. Information technologies as a factor of development of modern inclusive society. Gumanitarnye, social'no-jekonomicheskie i obshhestvennye nauki = Humanities, Socio-Economic and Social Sciences. 2015; 6 (1): 122-125. (In Russ.)

7. Volkova I. P., Pisarenko E. N. Value and ways of using of network computer technologies for visually impaired people. Gumanitarnye nauki = Humanita rian Sciences. 2017; 2 (38): 50-55. (In Russ.)

8. Koroleva N. N., Volkova I. P., Bogdanovskaya I. M. Social and psychological support for the visually impaired in a high-tech information environment. Pis'ma $v$ Emissiya. Offlajn = The Emissia. Offline Letters [Internet]. 2014 [cited 2019 Jun 2]; ART 2047. Available from: http://www.emissia.org/offline/2014/2247.htm (In Russ.)

9. Sorokina A. B. Internet in the life of modern children and adolescents: A problem and a resource. Sovremennaya zarubezhnaya psihologiya = Modern Foreign Psychology. 2015; 4 (1): 45-64. (In Russ.)

10. Marinova T. Yu., Zaretskaya O. V. Socio-psychological aspects of addiction on computer multiplayer online games-role-playing. Social'naya psihologiya $i$ obshchestvo = Social Psychology and Society. 2015; 6 (3): 109-119. DOI: 10.17759/sps.2015060308 (In Russ.)

11. Soldatova G. V., Olkina O. I. Cons of openness. Russian schoolchildren: Private information security in the network. Deti $v$ informacionnom obshchestve = Children in the Information Society. 2015; 20: 26-47. (In Russ.)

12. Egorov A. Yu. Modern views on Internet addiction and approaches to its correction. Meditsinskaya psikhologiya $v$ Rossii $=$ Medical Psychology in Russia [Internet]. 2015 [cited 2019 Sent 9]; 4 (33): 1-17. Available from: http://mprj.ru/ archiv_global/2015_4_33/nomer01.php (In Russ.)

13. Griffiths M. D. Problematic online gaming: Issues, debates and controversies. Meditsinskaya psikhologiya $v$ Rossii = Medical Psychology in Russia [Internet]. 2015 [cited 2019 Jun 2]; 4 (33): 5. Available from: http://mprj.ru/archiv_ global/2015_4_33/nomer09.php (In Russ.)

14. Pontes H. M., Kuss D. J., Griffiths M. D. Clinical psychology of Internet addiction: a review of its conceptualization, prevalence, neuronal processes, and implications for treatment. Neuroscience and Neuroeconomics [Internet]. 2015 [cited 2019 Jun 2]; 4: 11-23. Available from: https://doi.org/10.2147/NAN.S60982

15. Emelin V. A., Rasskazova E. I., Thostov A. Sh. Psychological consequences of the development of information technology. Nacional'nyj psihologicheskij zhurnal = National Psychological Journal. 2012; 1 (7): 81-87. (In Russ.)

16. Toncheva A. V. The problem cybercommunications addiction in adolescence. Vestnik chuvashskogo universiteta = Bulletin of Chuvash University. 2013; 1: 131-136. (In Russ.)

17. Savci M., Aysan F. Social-emotional model of Internet addiction. Klinik Psikofarmakoloji Bulteni. 2017; 27 (4): 349-358. DOI:10.1080/24750573.2017.1367552

Образование и наука. Том 21, № 9. 2019/The Education and Science Journal. Vol. 21, № 9. 2019 
18. Tao R., Huang X., Wang J., Zhang H., Zhang Y., Li M. Proposed diagnostic criteria for Internet addiction. Addiction. 2010; 105: 556-564.

19. Weinstein A. Internet addiction: Diagnosis, comorbidity and treatment. Medical Psychology in Russia. 2015; 4 (33): 1-24.

20. Davis R. A. A cognitive-behavioral model of pathological Internet use. Computers in Human Behavior. 2001; 17: 187-195. DOI:10.1016/S07475632(00)00041-8

21. Khodakovskaia O. V., Bogdanovskaya I. M., Koroleva N. N., Alekhin A. N., Lugovaya V. F. Problematic Internet Usage and the Meaning-Based Regulation of Activity Among Adolescents. In: Communications in Computer and Information Science. Digital Transformation and Global Society. Third International Conference. DTGS 2018 [Internet]; 2018 May 30 - June 2; St.-Petersburg, Russia. Springer, Cham; 2018 [cited 2019 Jun 2]; Vol. 859: 227-238. Available from: https://doi.org/10.1007/978-3-030-02846-6_18

22. Ericyan K. Yu, Antonova N. A., Marudova N. M. Problematic Internet Use and Internet-communication. Vestnik Sankt-Peterburgskogo universiteta: 16. Psihologiya. Pedagogika $=$ Bulletin of St.-Petersburg University. Series 16. Psychology. Pedagogy. 2013; 2: 15-22. (In Russ.)

23. Antonenko A. A. Psychopathological phenomena accompanying Internet-dependent behavior in adolescents and their prevention. Klinicheskaya $i$ medicinskaya psihologiya: issledovanie, obuchenie, praktika = Clinical and Medical Psychology: Research, Training, Practice [Internet]. 2015 [cited 2019 Jun 2]; 1 (7): 1-4. Available from: http://medpsy.com/climp/2015_1_7/article10.php (In Russ.)

24. Malygin V. L., Khomeriki N. S., Antonenko A. A. Individually-psychological qualities of adolescents as risk-factors for development of Internet-addictive behavior. Meditsinskaya psikhologiya $v$ Rossii = Medical Psychology in Russia [Internet]. 2015 [cited 2019 Jun 2]; 1 (30): 7. Available from: http://www.medpsy.ru/ mprj/archiv_global/2015_1_30/nomer10.php (In Russ.)

25. Griffiths M. D., Kuss D. J. Adolescent social media addiction (revisited). Education and Health. 2017; 35 (3): 49-52.

26. Sinkkonen H. M., Puhakka H. Meriläinen M. Internet use and addiction among Finnish Adolescents (15-19 years). Journal of Adolescence [Internet]. 2014 [cited 2019 Jun 2]; 37 (2): 123-131. Available from: https://doi.org/10.1016/ j.adolescence.2013.11.008

27. Good B. Fang L. promoting smart and safe internet use among children with neurodevelopmental disorders and their parents. Clinical Social Work Journal [Internet]. 2015; 43 (2): 179-188. Available from: https://doi.org/10.1007/ s10615-015-0519-4

28. Saifutdiyarova E. F., Fatihova L. F. Analysis of foreign research on the use of computer technology in the correctional and educational process of students with disabilities. Vestnik Marijskogo gosudarstvennogo universiteta $=$ Bulle tin of the Mari State University. 2017; 3 (27): 75-80. (In Russ.)

29. Balakrishnan J., Griffiths M. D. Social media addiction: What is the role of content in YouTube? Journal of Behavioral Addictions [Internet]. 2017 [cited 2019 Jul 2]; 5 (3): 1-15. Available from: DOI: 10.1556/2006.6.2017.058

30. Park S., Kim E. The relationship between online activities, netiquette and cyberbullying. Children and Youth Services Review [Internet]. 2014 [cited 
2019 JUL 2]; 42: 74-81. Available from: https://doi.org/10.1016/j.childyouth.2014.04.002

31. Vygotsky L. S. Istoriya razvitiya vysshih psihicheskih funkcij = History of the development of higher mental functions. Moscow: Publishing House Yurayt; 2018. 359 p. (In Russ.)

32. Yur'eva L. N., Bol'bot T. Yu. Komp'yuternaya zavisimost': formirovanie, diagnostika, korrekciya i profilaktika $=$ Computer addiction: Formation, diagnosis, correction and prevention. Dnepropetrovsk: Publishing House Porogi; 2006. 196 p. (In Russ.)

33. Goldberg I. Internet addiction disorder. Cyberpsychology and Behavior. 1996; 3 (4): 403-412.

34. Orzack M. H. Computer addiction: What is it? Psychiatric Times. 1998; 15 (8): 34-38.

35. Lidström H., Ahlsten G., Hemmingsson H. The influence of ICT on the activity patterns of children with physical disabilities outside school. Child: Care, Health and Development. 2011; 37: 313-321. DOI:10.1111/j.1365-2214.2010.01168.x

36. Korobejnikov I. A. Narusheniya razvitiya i social'naya adaptaciya $=$ Developmental disabilities and social adaptation Moscow: Publishing House PER SE; 2002. 192 p. (In Russ.)

37. Rychkova L. S. disorders in the structure of school maladaptation in adolescents with mild mental retardation. Reabilitaciya $v$ narkologii $=$ Rehabilitation in Narcology. 2002; 1: 84-88. (In Russ.)

38. Litvak A. G. Psihologiya slepyh i slabovidyashchih = Psychology of the blind and visually impaired. St. Petersburg: Publishing House Karo; 2006. 336 p. (In Russ.)

39. Volkova I. P. Social'naya integraciya invalidov po zreniyu: psihologicheskie aspekty $=$ Social integration of people with visually impaired: Psychological aspects. Saint-Petersburg: Herzen State Pedagogical University of Russia; 2012. 203 p. (In Russ.)

40. Kostyuchenko E. S. Internet communication in the life of people with vision disorders. Lzvestiya Irkutskogo gosudarstvennogo universiteta. Serija: Psihologija = Bulletin of Irkutsk State University. Series: Psychology. 2014; 9: 23-29. (In Russ.)

\section{Список использованных источников}

1. Chakraborty J., Chakraborty S., Dehlinger J. et al. Designing video games for the blind: results of an empirical study // Universal Access in the Information Society. 2017. № 16 (3). P. 809-818. DOI: 10.1007/s10209-016-0510-z

2. Haage A., Bosse I. K. Media Use of Persons with Disabilities. Universal Access in Human-Computer Interaction // Human and Technological Environments. Lecture Notes in Computer Science. Springer, Cham. 2017. 10279. DOI: 10.1007/978-3-319-58700-4_34

3. Sallafranque-St-Louis F., Normand C. L. From solitude to solicitation: How people with intellectual disability or autism spectrum disorder use the Internet // Cyberpsychology: Journal of Psychosocial Research on Cyberspace. 2017. № 11 (1). article 7. DOI: 10.5817/CP2017-1-7 
4. Белозеров С. А. Виртуальные миры MMORPG: часть II. Средство от социально-психологического стресса [Электрон. ресурс] // Психология: журнал Высшей школы экономики. 2015. Т. 12, № 1. С. 71-89. Режим доступа: https://psyjournal.hse.ru/data/2015/05/19/1097217643/PJHSE_1_2015_71_89.pdf

5. Александрова М. А., Живайкина А. А. Роль Интернета в социализации

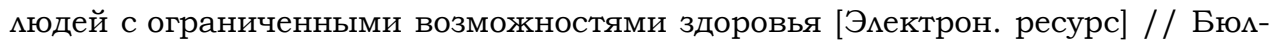
метень медицинских Интернет-конференций. 2017. № 7 (1). Режим доступа: https:/ / medconfer.com/node/11264 (дата обращения: 29.09.2019)

6. Бухтиярова И. Н. Информационные технологии как фактор развития современного инклюзивного общества [Электрон. ресурс] // Гуманитарные, социально-экономические и общественные науки. 2015. № 6 (1). С. 122-125. Режим доступа: https://cyberleninka.ru/article/n/informatsionnye-tehnologiikak-faktor-razvitiya-sovremennogo-inklyuzivnogo-obschestva (дата обращения: 29.09.2019)

7. Волкова И. П., Писаренко Е. Н. Значение и особенности использования инвалидами по зрению компьютерных сетевых технологий // Гуманитарные науки. 2017. № 2 (38). С. 50-55.

8. Королева Н. Н., Волкова И. П., Богдановская И. М. Социально-психомогическая поддержка инвалидов по зрению в высокотехнологичной информационной среде [Эмектрон. ресурс] // Письма в Эмиссия. Оффмайн (Тhе Emissia. Offline Letters): электронный научный журнал. 2014. ART 2047. Peжим доступа: http://www.emissia.org/offline/2014/2247.htm

9. Сорокина А. Б. Интернет в жизни современных детей и подростков: проблема и ресурс // Современная зарубежная психология. 2015. Т. 4, № 1 . C. $45-64$.

10. Маринова Т. Ю., Зарецкая О. В. Социально-психологические аспекты зависимости от компьютерных ролевых онлайн-игр // Социальная психомогия и общество. 2015. № 6 (3). С. 109-119. DOI: $10.17759 / \mathrm{sps} .2015060308$

11. Солдатова Г. В., Олькина О. И. Минусы открытости. Российские школьники: Аичная информация и безопасность в сети // Дети в информационном обществе. 2015. № 20. С. 26-47.

12. Егоров А. Ю. Современные представления об интернет-аддикциях и подходах к их коррекции [Электрон. ресурс] // Медицинская психология в России: эмектрон. науч. журн. 2015. № 4 (33). С. 1-17. Режим доступа: http://mprj.ru/archiv_global/2015_4_33/nomer01.php (дата обращения: 29.09.2019)

13. Griffiths M. Problematic online gaming: Issues, debates and controversies // Medical psychology in Russia. 2015. № 4 (33). Р. 5. Режим доступа: http://www.medpsy.ru/mprj/archiv_global/2015_4_33/nomer09.php (дата обращения: 29.09.2019)

14. Pontes H. M., Kuss D. J., Griffiths M. D. Clinical psychology of Internet addiction: a review of its conceptualization, prevalence, neuronal processes, and implications for treatment // Neuroscience and Neuroeconomics. 2015. № 4. P. 11-23. DOI: 10.2147/NAN.S60982

15. Емелин В. А., Рассказова Е. И., Тхостов А. Ш. Психологические посмедствия развития информационных технологий // Национальный психологический журнал. 2014. № 5. С. 67-69.

Образование и наука. Том 21, № 9. 2019/The Education and Science Journal. Vol. 21, № 9. 2019 
16. Тончева А. В. Проблема киберкоммуникативной зависимости в подростковом возрасте // Вестник ЧГУ. 2013. № 1. С. 131-136.

17. Savci M., and Aysan F. Social-emotional model of Internet addiction // Klinik Psikofarmakoloj i Bulteni. 2017. № 27 (4). P. 349-358. DOI: 10.1080/ 24750573.2017.1367552

18. Tao R., Huang X., Wang J., Zhang H., Zhang Y., \& Li M. Proposed diagnostic criteria for Internet addiction // Addiction. 2010. № 105. P. 556-564.

19. Weinstein A. Internet addiction: diagnosis, comorbidity and treatment [Э九ектрон. pecypc] // Medical psychology in Russia. 2015. № 4 (33). P. 1-24. Peжим доступа: https://doi.org/10.1016/j.addbeh.2014.07.031

20. Davis R. A. A cognitive-behavioral model of pathological Internet use // Computers in Human Behavior. 2001. № 17. P. 187-195. DOI: 10.1016/S07475632(00)00041-8

21. Khodakovskaia O. V., Bogdanovskaya I. M., Koroleva N. N., Alekhin A. N., Lugovaya V. F. Problematic Internet Usage and the Meaning-Based Regulation of Activity Among Adolescents // Digital Transformation and Global Society. Communications in Computer and Information Science. 2018. № 859. P. 227-238. DOI: 10.1007/978-3-030-02846-6_18

22. Ерицян К. Ю., Антонова Н. А., Марудова, Н. М. Проблемное использование Интернета в контексте Интернет-коммуникации // Вестник Санкт-Петербургского университета. Серия 16: Психология. Педагогика. 2013. № 2. С. 15-22.

23. Антоненко А. А. Психопатологические феномены, сопровождающие интернет-зависимое поведение у подростков и их профицактика [Электрон. ресурс] // Клиническая и медицинская психология: исследования, обучение, практика. 2015. № 1 (7). С. 1-4. Режим доступа: http://medpsy.com/climp/ 2015_1_7/article10.php

24. Малыгин В. А., Х Хомерики Н. С., Антоненко А. А. Индивидуальнопсихологические свойства подростков как факторы риска формирования интернет-зависимого поведения // Медицинская психология в России. 2015. № 7 (30). С. 7 [Электрон. ресурс]. Режим доступа: http://www.medpsy.ru/ mprj/archiv_global/2015_1_30/nomer10.php

25. Griffiths M. D., Kuss D. J. Adolescent social media addiction (revisited) // Education and Health. 2017. № 35 (3). P. 49-52.

26. Sinkkonen H. M., Puhakka H., Meriläinen M. Internet use and addiction among Finnish Adolescents (15-19 years) // Journal of Adolescence. 2014. № 37 (2). P. 123-131. DOI: https://doi.org/10.1016/j.adolescence.2013.11.008

27. Good B., Fang L. Promoting Smart and Safe Internet Use Among Children with Neurodevelopmental Disorders and Their Parents // Clinical Social Work Journal. 2015. № 43 (2). P. 179-188. DOI: https://doi.org/ $10.1007 / \mathrm{s} 10615-015-0519-4$

28. Сайфутдиярова Е. Ф., Фатихова $\Lambda$. Ф. Анализ зарубежных исследований по проблеме использования компьютерных технологий в коррекционно-образовательной работе с учащимися с ОВЗ // Вестник Марийского государственного университета. 2017. № 3 (27). С. 75-80.

29. Balakrishnan J., Griffiths M. Social media addiction: What is the role of content in YouTube? // Journal of Behavioral Addictions. 2017. № 5. P. 1-15. DOI: $10.1556 / 2006.6 .2017 .058$

Образование и наука. Том 21, № 9. 2019/The Education and Science Journal. Vol. 21, № 9. 2019 
30. Park S., Kim E. The relationship between online activities, netiquette and cyberbullyng // Children and Youth Services Review. 2014. № 42. C. 74-81. DOI: $10.1016 /$ j.childyouth.2014.04.002

31. Выготский $\Lambda$. С. История развития высших психических функций. Москва: Юрайт, 2018. 359 с.

32. Юрьева $\Lambda$. Н., Больбот Т. Ю. Компьютерная зависимость: формирование, диагностика, коррекция и профимактика: монография. Днепропетровск: Пороги, 2006. $196 \mathrm{c}$.

33. Goldberg I. Internet addiction disorder // Cyberpsychology and Behavior. 1996. № 3 (4). P. 403-412.

34. Orzack M. H. Computer addiction: What is it? // Psychiatric Times. 1998. № 15 (8). P. 34-38.

35. Lidström H., Ahlsten G. Hemmingsson H. The influence of ICT on the activity patterns of children with physical disabilities outside school // Child: Care, Health and Development. 2011. № 37. P. 313-321. DOI: 10.1111/j.13652214.2010.01168.x

36. Коробейников И. А. Нарушения развития и социальная адаптация. Москва: ПЕР СЭ, 2002. 192 с.

37. Рычкова $\Lambda$. С. Аддиктивные расстройства в структуре школьной дезадаптации у подростков с мегкой умственной отсталостью // Реабилитация в наркологии. 2002. № 1. С. 84-88.

38. Аитвак А. Г. Психология слепых и слабовидящих: учебное пособие для студентов высших педагогических учебных заведений. С.-Петербург: Каpo, 2006. 336 c.

39. Волкова И. П. Социальная интеграция инвалидов по зрению: психомогические аспекты: учебное пособие дмя студентов высших учебных заведений, обучающихся по направлению 050100 - Педагогическое образование. С.Петербург: РГПУ им. А. И. Герцена, 2012. 203 с.

40. Костюченко Е. С. Роль интернет-коммуникаций в жизни инвалидов по зрению // Известия Иркутского государственного университета. 2014. Серия: Психология. № 9. С. 23-290.

\section{Information about the authors:}

Irina P. Volkova - Doctor of Pedagogical Sciences, Associate Professor, Department of Basics of Special Education, Herzen State Pedagogical University of Russia, St. Petersburg, Russia.E-mail: volkova52@mail.ru

Natalya N. Koroleva - Doctor of Psychological Sciences, Professor, Department of Psychology of Professional Activity, Herzen State Pedagogical University of Russia, St. Petersburg, Russia. E-mail: korolevanatalya@mail.ru

Irina M. Bogdanovskaya - Candidate of Psychological Sciences, Associate Professor, Department of Psychology of Professional Activity, Herzen State Pedagogical University of Russia, St. Petersburg, Russia. E-mail: ibogdanovs@herzen.spb.ru

Galina Yu. Ikonnikova - Candidate of Psychological Sciences, Associate Professor, Department of Psychology of Professional Activity, Herzen State Pedagogical University of Russia, St. Petersburg, Russia. E-mail: ikonnikova@inbox.ru 
Antonina V. Mashkova - Post-Graduate Student, Department of Oligophrenopedagogy, Herzen State Pedagogical University of Russia, Saint-Petersburg, Russia. E-mail: amashkova@herzen.spb.ru

\section{Contribution of the authors:}

I. P. Volkova - theoretical and methodological foundations of the study, organisation of monitoring of the results of interaction of adolescents with disabilities with modern information technology, literature analysis and formulation of the research problem.

N. N. Koroleva - definition of goals and objectives of studying the specifics of interaction of adolescents with limited opportunities with modern information technologies, preparation of the plan, research program.

I. M. Bogdanovskaya - methodological support, mathematical and statistical processing of empirical data, analysis and interpretation of research results.

G. Yu. Ikonnikova - generalisation of research results, their discussion and writing conclusions on the results of the study.

A. V. Mashkova - preparation of psychodiagnostic methods for work with adolescents with disabilities, conducting empirical research, primary qualitative and quantitative processing of empirical data.

Received 23.04.2019; accepted for publication 16.10.2019.

The authors have read and approved the final manuscript.

\section{Информаиия об авторах:}

Вомкова Ирина Павмовна - доктор педагогических наук, доцент кафедры основ коррекционной педагогики Российского государственного педагогического университета им. А. И. Герцена; ORCID ID: 0000-0002-88122832, Researcher ID: Y-8457-2018; Санкт-Петербург, Россия. E-mail: volkova52@mail.ru

Коромева Наталья Никомаевна - доктор психологических наук, профессор кафедры психологии профессиональной деятельности Российского государственного педагогического университета им. А. И. Герцена; ORCID ID: 0000-0003-4399-6330, Researcher ID: D-9910-2017; Санкт-Петербург, Россия. E-mail: korolevanatalya@mail.ru

Богдановская Ирина Марковна - кандидат психологических наук, доценткафедры психологии профессиональной деятельности Российского государственного педагогического университета им. А. И. Герцена; ORCID ID: 0000-0001-7303-615X, Researcher ID: D-8804-2017, Scopus Author ID: 57192820293; Санкт-Петербург, Россия. E-mail: ibogdanovs@herzen.spb.ru

Иконникова Гахина Юрьевна - кандидат психологических наук, доцент кафедры психологии профессиональной деятельности Российского госу- 
дарственного педагогического университета им. А. И. Герцена; Researcher ID: D-9800-2017; Санкт-Петербург, Россия. E-mail: ikonnikova@inbox.ru

Машкова Антонина Вмадимировна - аспирант кафедры олигофренопедагогики Российского государственного педагогического университета им. А. И. Герцена; ORCID ID:0000-0002-9319-2456, Researcher ID: D-97922017; Санкт-Петербург, Россия. E-mail: amashkova@herzen.spb.ru

\section{вклад соавторов:}

И. П. Волкова - определение теоретико-методологических основ исследования, организация мониторинга результатов взаимодействия подростков с ограниченными возможностями с современными информационными техномогиями, анализ митературы и постановка проблемы исследования.

Н. Н. Королева - определение целей и задач изучения специфики взаимодействия подростков с ограниченными возможностями с современными информационными технологиями, подготовка плана, программы исследования.

И. М. Богдановская - методическое обеспечение, математико-статистическая обработка эмпирических данных, анализ и интерпретация результатов исследования.

Г. Ю. Иконникова - обобщение результатов исследования, их обсуждение и написание заключения по результатам исследования.

А. В. Машкова - подготовка психодиагностических методик дмя работы с подростками с ОВЗ, проведение эмпирического исследования, первичная качественная и количественная обработка эмпирических данных.

Статья поступила в редакцию 23.04.2019; принята в печать 16.10.2019. Авторы прочитали и одобрили окончательный вариант рукописи. 